\title{
Web-Environment Supervision as a New Form of Internet Socialization
}

\author{
Marina S. Chvanova ${ }^{1}$, Ekaterina D. Saushkina ${ }^{2}$ \\ Department of Information Systems and Technologies \\ K.G. Razumovsky Moscow State University of Technologies and Management (the First Cossack University) \\ Moscow, Russia \\ 1tmbtsu@gmail.com, ${ }^{2}$ tmbtsu@gmail.com \\ Maria S. Anurieva ${ }^{3}$, Alexey V. Samokhvalov ${ }^{4}$, Anatoly A. Molchanov ${ }^{5}$ \\ Department of Mathematical Modeling and Information Technologies \\ G.R. Derzhavin Tambov State University \\ Tambov, Russia \\ ${ }^{3}$ anuryeva@mail.ru, ${ }^{4}$ samohvalov@gmail.com, ${ }^{5}$ ykdosto@gmail.com
}

\begin{abstract}
The article considers the issues of Internetsocialization of computer science students as a part of their interaction with professional community on current problems of the subject field that are in constant transformation. Results of innovation course "Information Reengineering" design, based on informational and educational system modeling, are presented in the article.
\end{abstract}

Key words: information reengineering, Internet socialization.

\section{INTRODUCTION}

One of the main problems associated with the training of modern personnel is the creation of conditions conducive to the development of specialists capable of solving professional tasks that are continuously being modified, and, as a result, the methods, means and technologies for solving them are changing. The need for constant interaction of educational process participants in professional community is increasing. This is expressed not only in the need to attract specialists from among the managers and employees of organizations whose activities are related to the specialization of the educational program being implemented, as faculty members, but also in their active participation in the formation of basic educational programs, the creation of new academic disciplines and practice programs. This problem is particularly acute in the training of IT professionals, when the subject field of studied disciplines is in constant transformation: not only the content of previously taught disciplines changes continuously, but completely new ones appear.

For example, due to the adoption of the Concept of Information Society Development in Russia for 2017-2030, a number of directions for the development of Russian information and communication technologies have been formed and identified: Internet of Things and the Industrial Internet, Big Data processing, cloud and fog computing, trusted technologies of electronic identification and authentication including financial sphere and others.

At the same time, educational disciplines and their components are not formed due to the emergence of new knowledge. The understanding of a new subject field often occurs during the process of analyzing and integrating professional practice. At the same time, discussion of topical issues by students and representatives of professional community is very important for the professional socialization of young people.

\section{RESEARCH}

Communication with professional community in the process of learning through project activities.

One of the objectives of the national priority project "Science" is creation of world-class scientific and educational centers based on universities and research organizations, their cooperation with the professional community operating in the real sector of the economy. Training of modern personnel should be carried out in conditions conducive to the development of specialists capable of solving professional tasks that are continuously transforming, and their solution requires the use of new tools, which leads to an improvement in quality (the emergence of new methods and technologies) and quantitative (increase in execution speed, volume of tasks) results. Professional tasks can both be transformed from old ones, adapting to the new conditions of scientific and technical progress, and be fundamentally new, not previously solved, and requiring fundamentally new means, methods and solutions [14]. This forces the process of training specialists to constantly make changes in both the content and the organization.

Knowledge of the fundamentals of project, research, innovation activity, introduction of entrepreneurial ideas into the content of existing courses are becoming especially necessary [5].

Various pedagogical technologies (project method, problembased training, etc.) make it possible to solve the tasks in some way. At the same time, in the conditions of the information society, their use without reliance on modern management technologies and information tools will not significantly improve the educational process. Project activities of students, which are integrated into the needs of the professional community, are coming to the fore. At the same time, the former management methods do not allow solving promising tasks, and the methods and technologies used today have become 
insufficient to integrate educational projects into the professional field.

The above makes it necessary to consider the logic and algorithm of the organization of project activities in Webenvironment for training high school students.

The general idea of the organization of project activities in high school is as follows. First of all, it is the solution of an urgent task, significant for the student, preparing him for future activities in the modern information society and in the real sector of the economy. Students acquire not only professional competence in design and technological activities, but also experience in teamwork, experience of interaction with colleagues and customers. Organizational and administrative competencies are formed; future IT specialist is socialized in professional community. Experience of project work increases the competitiveness of future specialists on the job market, helps to take the first step in building a successful career.

The system of communications provides various components of interaction of participants of educational process in web environment [6]: computer "imitation" of communication in traditional learning systems at the university. Since, we are talking about the training of computer science students, it is important to build additional elements to solve professional problems and carry out specific types of communication in the system. These elements are:

- Communication between student and professionally oriented community communication (search for problems in professional field, search for potential partners for a project).

- Communication between student and world information space communication (interaction in the global intellectual community of professionals, consultations are sought and carried out to find solutions to professional problems and potential project participants).

- Communication between student and innovative infrastructures communication (characteristic feature of the information industry is research activity, while relevant employees must have the skills, forecasting techniques, readiness to work in new areas and activities). A specialist must be able "to sell" a relevant product, economically and efficiently explaining the benefits and corresponding risks in development of hightech products. This forces to include in to the developing model not only "classical" elements of pedagogical system as a teacher and a student, but also an innovation infrastructure, e.g. technology transfer centers, centers of marketing research, business incubators. "Open" system involves interaction with external system components, e.g. venture funds, representatives of academic community, digital libraries).

\section{Organization of communication in the Internet and} automation of project management.

Management of innovative educational projects is one of the most difficult and labor-intensive areas of management. Project's success is determined by the efficiency of realization of project's idea, where the interests of teams and organizations working on project's implementation are concentrated. Effective implementation of the project intent is possible only with a coordinated purposeful development of all processes that ensure this implementation, with effective management of the project implementation process.

The project management process is presented in the form of a sequence of the following steps:

- defining of goals, sub-goals and objectives;

- $\quad$ identifying the resources needed to complete tasks;

- drawing up a project implementation plan;

- $\quad$ initiating the process of starting implementation;

- $\quad$ project development tracking [7].

When developing a web-based environment for communication of subjects of the educational process with the professional community, the possibility of passing each step should be realized.

\section{Web-environment for socialization of students in} professional community.

The high dynamics of development of the subject field and courses studied by computer science students necessitates the constant transformation not only of content, but also of educational technologies. Actual educational disciplines are often set forth fragmentary and not formed due to the formation of a new knowledge. Understanding of the new subject field occurs in the process of theoretical analysis and professional practice. It happened, for example, with the development of the concept of "Information reengineering". Components of this process have long been used in various areas of computer science, but a holistic view is not yet sufficiently meaningful. The above dictates the need to create a new course "Information Reengineering" based on modeling a web environment to support student's training. In this case, the term "information and education system" means a complex that includes computing and communication equipment, software and personnel, providing support for a constantly changing information system.

The set of elements included in the structure is determined by the purpose of the system, in our case we mean the improvement of training and virtual socialization of computer science students in a particular educational institution or as a model for a group of universities that train specialists of the same profile.

The content of ILE was formed according to knowledge and skills necessary to perform labor functions in information reengineering, identified in professional standards for informatics (№ 616N “Information Technology Manager” [8], № 645N "Head of software development” [9], № 893N “Project Manager in the field of information technologies" [10]).

Professional standards determine not only the profession and generalized work functions, but also the qualification level of a specialist, as well as the scope of application and specific work activities, the necessary knowledge and skills in performing these functions. The range of duties have a clearly defined information orientation, while the need for knowledge of 
information reengineering processes is not reflected in the standards, which indicates a lack of attention to the on-time elimination of problems in the information processes of enterprises.

The educational course we have created contains theoretical material, laboratory work, practical tasks, and test tasks on the topics of "Information Reengineering", which are necessary to solve the tasks set for a future specialist.

The material is divided into 3 units of "Information reengineering" topics:

- The first one includes means of identification organization's IT resources needs, ways to identify IT service needs and change management.
- The second unit includes technical specification of software, team information exchange.

- The third block includes quality management in IT projects, requests for changes in IT projects, improvement of the efficiency of project management system and risk management in IT projects.

"Information Reengineering" web-system was posted on the Internet (Fig. 1); Information Reengineering group was created in Vkontakte social network (Fig. 2). Communication in the group contributes to the online socialization of students in professional community when discussing the problems of new knowledge development.

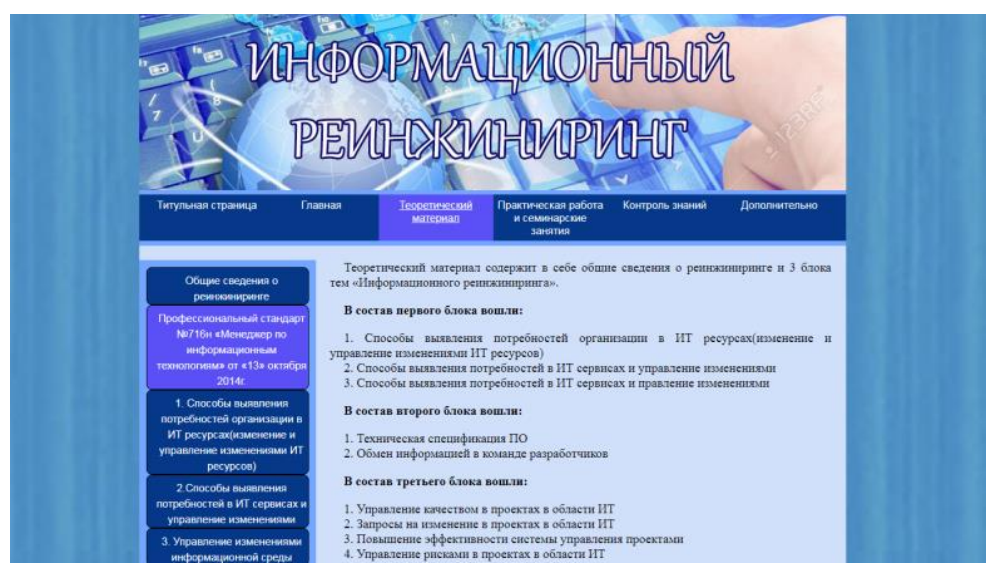

Fig. 3. Page of informational educational system "Information reengineering"

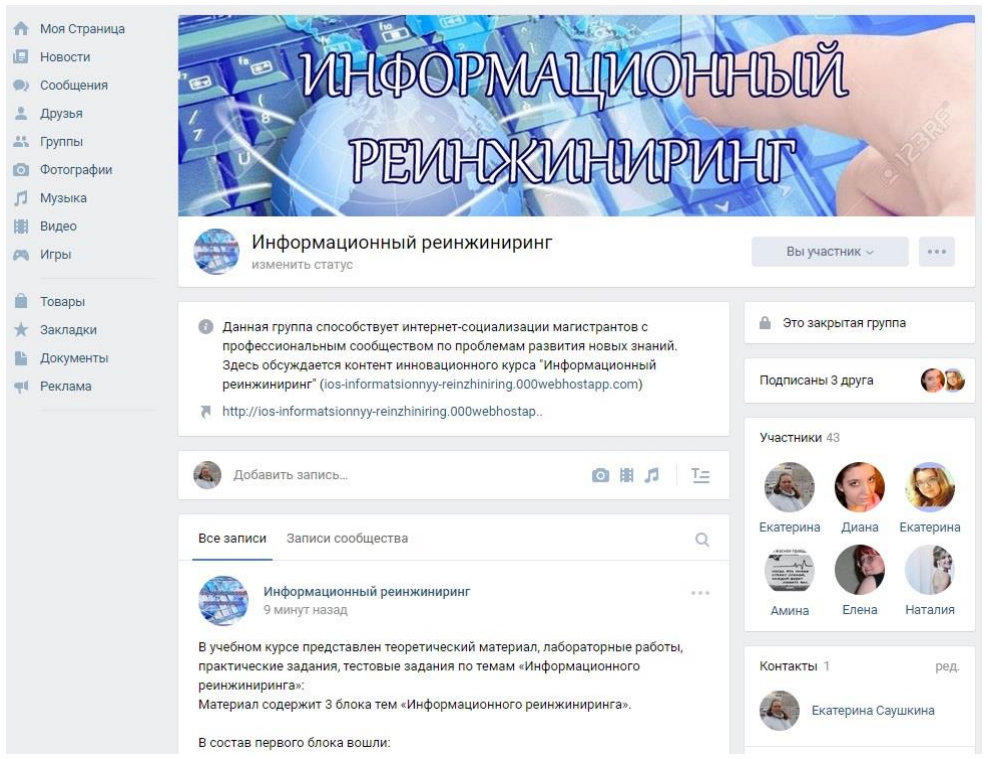

Fig. 4. Group in the social network "Vkontakte"

\section{RESULTS OF THE STUDY}

Educational process of training computer science students is currently carried out in high dynamics conditions of studied disciplines' subject field. New disciplines are being introduced; traditional disciplines are being modified by including new topics: the Internet of Things, Industrial Internet, block chain, smart technologies, information reengineering, Big Data. A joint discussion of new problems of computer science by students and representatives of professional community actualizes the 
creation of specialized web environment that contributes to professional socialization of young people.

Web environment provides various components for interaction of educational process participants, which include the following elements: communication between student and professionally-oriented community, between student and world information space. between student and innovative infrastructures.

Results of our research are implemented in practice of quality management of educational process in K.G. Razumovsky Moscow State University of Technologies and Management (the First Cossack University) and G.R. Derzhavin Tambov State University. Approbation of the "Information reengineering" course for computer science master degree students proved the desirability of its use. Reengineering of information processes is used both in production and banking, as well as in education, medicine, telecommunications, etc.

The study does not exhaust the full extent of the problem of socialization of computer science students in professional community, but it also provides an effective solution to one of the important problems. Obtained results can be used to further study the patterns, principles and features of Internet socialization of students in professional community. Developed web environment (for supervision of training computer science students in new course "Information Reengineering") has a great educational potential and contributes to development of Internet socialization in professional community.

The results obtained with financial support of the Russian Foundation of Basic Research for the project "Sociological analysis of the Internet space as an indicator of the socio-cultural dynamics of the development of open education", No 16-0600176, 2016-2018.

Certain aspects investigated and the corresponding results obtained with financial support of the Russian Foundation of Basic Research for the project "Pedagogical basics of youth students' socialization in Internet space and their implementation in educational system", No 17-36-00039, 20172019.

\section{REFERENCES}

[1] Быков А.Н. Инновационная политика в условиях глобализации // Актуальные проблемы развития мировой экономики: Сб. ст. M., 2007. C. 32-50. [Bykov A.N. Innovation policy in the context of globalization // Actual problems of the global economy: a collection of articles. Moscow, 2007. P. 32-50].

[2] Добрынин А.И., Ивлева Е.С. К вопросу о модернизации модели выцсшего образования в России // Экономика и управление.. 2011. № 5. C. 128-134. [Dobrynin A.I., Ivleva E.S. On the issue of modernization of the higher education model in Russia // Economics and Management. 2011. N 5. P. 128-134ъ.
[3] Чванова М.С., Лыскова В.Ю. Кластерный подход: профессионально-ориентированнная информационно-учебная вики-среда для студентов-информатиков // Вестник Тамбовского университета. Сер. Гуманитарные науки. 2012. № 10. C. 130-134. [Chvanova M.S., Lyskova V.Yu. Cluster approach: professionally-oriented informational and educational wiki environment for computer science students // Bulletin of Tambov University. Series: The humanities. 2012. N 10. P. 130-134].

[4] Юрьев В.М., Чванова М.С, Теоретические основы подготовки специалистов наукоемких специальностей: становление унимверситета как центра инновационно-образовательного кластера // Вестник Тамбовского университета. Сер. Гуманитарные науки. 2007. № 10. C. 7-10. [Yuriev V.M., Chvanova M.S. Theoretical bases of training specialists of science intensive specialties: University development as a centre of innovation education cluster // Bulletin of Tambov University. Series: The humanities. 2007. N 10. Р. 7-13].

[5] Чванова М.С., Малышева Н.В., Киселева И.А. и др. Проектная деятельность студентов и школьников на основе кластерного подхода // Вестник Тамбовского университета. Сер. Гуманитарные науки. 2009. № 9. C. 240-253. [Chvanova M.S., Malysheva N.V., Kiseleva I.A. et al. Project activity of students and schoolchildren based on the cluster approach // Bulletin of Tambov University. Series: The humanities. 2009. N 9. Р. 240-253].

[6] Юрьев В.М., Чванова М.С. Кластерный подход в подготовке специалистов наукоемких специальностей // Вестник Тамбовского университета. Сер. Гуманитарные науки. 2009. № 5. C. 872-876. [Yuryev V.M., Chvanova M.S. Cluster approach to the training of high-tech specialists // Bulletin of the Tambov University. Series: Natural and Technical Sciences. 2009. N 5. P. 872-876].

[7] Чванова М.С., Храмова М.В. Проблемы организации коммуникаций студентов наукоемких специальностей в системе открытого образования // Образовательные технологии и общество. 2011. № 2. С. 482-501. [Chvanova M.S., Khramova M.V. Problems of organizing communications of high-tech students in an open education system // Educational Technologies and Society. 2011. N 2. Р. 482-501].

[8] Приказ Минтруда России от 13.10.2014 № 716н «Об утверждении профессионального стандарта "Менеджер по информационным технологиям"». [Order of the Ministry of Labor of Russia, October 13, 2014 No. 716N "On approval of the professional standard" Information Technology Manager"]. URL: http://fgosvo.ru/uploadfiles/profstandart/06.014.pdf.

[9] Приказ Минтруда России от 17.09.2014 № $645 \mathrm{H}$ «Об утверждении профессионального стандарта "Руководитель разработки программного обеспечения"». [Order of the Ministry of Labor of Russia, September 17, 2014 No. 645N "On approval of the professional standard" Head of software development"]. URL: http://fgosvo.ru/uploadfiles/profstandart/06.017.pdf.

[10] Приказ Минтруда России от 18.11.2014 № $893 \mathrm{H}$ «Об утверждении профессионального стандарта "Руководитель проектов в области информационных технологий”» [Order of the Ministry of Labor of Russia, November 18, 2014 No 893N “On the approval of professional standard "Project Manager in the field of information technologies"]. URL: http://fgosvo.ru/uploadfiles/profstandart/06.016.pdf. 